\title{
A Szlovák Köztársaság ügyészsége - alkotmányos helyzet és törvényi szabályozás
}

A szlovákiai ügyészség alkotmányos jogállása és törvényi szabályozása hosszú ideje vita tárgya. Az érdeklődés egyik oka kétségkívül az, hogy az ügyészség tevékenységének, hatáskörének szabályozása a szakmai és a laikus nyilvánosságot is érinti. A figyelem elsősorban az ügyészség alkotmányos helyzetére, az ügyészség egyes szintjei, továbbá az ügyészség és a közhatalom más szervei közötti viszonyokra, valamint a büntetőügyek területén érvényesülő, s azokon kívüli hatáskörre irányul. Ez a tanulmány is e viszonyok tisztázására, a Szlovák Köztársaság ügyészségére vonatkozó régi és újabb közjogi rendelkezések bemutatására vállalkozik.

\section{1. Általában az ügyészségröl}

Az ügyészség jelenlegi szabályozása történelmi hagyományokon nyugszik. $A z$ ügyészség intézménye hosszú fejlődésen ment keresztül, különböző funkciókat töltött be, amíg olyan intézménnyé formálódott, amilyennek ma ismerjük. Az ügyészségnek valamennyi európai országban feladata, hogy üldözze a bủncselekményt megalapozó, normától eltérő magatartásokat. Ebből nem következik, hogy az európai országok minden ügyészsége hasonló szervezeti struktúrával vagy azonos jogosultságokkal rendelkezne. Az ügyészségek helyzete az egyes országok alkotmányos berendezkedéseiben jelentős eltéréseket mutat. Az eltérő rendszerek a különböző jogi kultúrákban gyökereznek, s nem létezik minden ország számára érvényes, egységes modell. Hangsúlyozni kell, hogy az ügyészségek minden típusa működőképes, és helyzetük szempontjából annak megítélése a mérvadó, hogy az adott államban közülük melyik felel meg jobban a demokratikus jogállam követelményeinek.

\section{Az ügyészség alkotmányos helyzete}

A Szlovák Köztársaság Alkotmánya (a továbbiakban: Alkotmány) olyan intézményként határozza meg az ügyészséget, amely a törvényesség jogi garanciáit jelentő rendszer szerves alkotóeleme a demokratikus jogállamban. A természetes és jogi

Doc. JUDr. Jozef Čentéš PhD, ügyész, egyetemi docens, a Szlovák Köztársaság Legföbb Ügyészsége, Komenský Egyetem Jogtudományi Kar (Pozsony). Jozef.Centes@flaw.uniba.sk. A cikk A jog kontinuitása és diszkontinuitása a 20. századi Szlovákiában, és hatása a Szlovák Köztársaság jogrendjére címü projekt keretén belül készült; a projektet a Tudományt és Kutatást Támogató Ügynökség (Agentúra pre podporu vedy a výskumu) részesítette támogatásban; száma APVV-0607-10. 
személyek, valamint az állam jogainak és törvénnyel védett érdekeinek a védelmezése tartozik a hatáskörébe. Ez annyit jelent, hogy a Szlovák Köztársaság ügyészségének hatáskörét az Alkotmány nem szükíti le az állam törvényes védelmezésére: azaz a Szlovák Köztársaság ügyészsége nem állami képviselet.

Az Alkotmány igencsak sajátságos formában hozza létre az ügyészséget, hiszen azt a közhatalmi szervek három alrendszerének, a klasszikus hatalmi ágak egyikébe sem lehet fenntartások nélkül beilleszteni. Az Alkotmány ugyanis nem sorolja be az ügyészséget sem a törvényhozói hatalom szervei (ötödik fejezet), sem a végrehajói hatalom szervei (hatodik fejezet), sem pedig a bírói hatalom szervei közé (hetedik fejezet). Az Alkotmány az ügyészséggel kapcsolatos rendelkezéseket szándékosan egy önálló, nyolcadik fejezetben foglalja össze, $A$ Szlovák Köztársaság ügyészsége és az állampolgári jogok biztosa cím alatt, a közhatalom fentebb említett szerveinek helyzetét szabályozó rendelkezésektöl elkülönítve. ${ }^{1}$ Erre utal az Alkotmányhoz készült indoklás is: „Az alkotmányosság alapelveiből és a törvény szuverenitásának princípiumaiból, valamint a polgárok alkotmányos jogainak és szabadságjogainak bírói védelemben testet öltő prioritásából kiindulva az ügyészség a törvényesség jogi garanciáit jelentő rendszer szerves alkotóeleme a demokratikus jogállamban. Az állam, valamint a természetes és jogi személyek jogainak és törvénnyel védelmezett érdekeinek a védelméből azáltal veszi ki a részét, hogy a jogi felelősség érvényre juttatása és a törvénytelenség orvoslásának biztosítása érdekében tevékenykedik. Nem helyettesíti se a végrehajtói, se a bírói hatalom szerveit. Az ügyészség helyzetének és hatáskörének pontos körülhatárolása érdekében kívánatos, hogy mindkettőt maga az Alkotmány határolja körül [...]. A hatáskörre való tekintettel az ügyészség éppúgy nem lehet a bíróságok, mint az államigazgatás valamelyik szervének az alkotórésze. Ennélfogva az Alkotmány tervezete feltételezi az ügyészségi szervek rendszerének a megőrzését, élén a Szlovák Köztársaság legföbb ügyészével, akit az államfő fog kinevezni a Szlovák Nemzeti Tanács javaslatára."

Az Alkotmány a közhatalom önálló szerveként hozza létre az ügyészséget, amely tehát nem része a törvényhozó hatalomnak (hiszen nem ad ki ún. elsődleges jogszabályokat), éppígy nem tartozik a végrehajtó hatalomhoz sem (nem jogosult rendeletek kiadására, nem sújtja jogi szankciókkal a jogszabályokat megsértő személyeket, nem ellenőrzi a normák végrehajtásának célszerüségét és hatékonyságát, csak a törvényességüket felügyeli), és bírósági jogköre sincs (nem dönt el jogvitákat az állam nevében). Olyan sui generis közhatalmi szerv tehát, amely magán viseli a végrehajtói hatalom ismertetőjegyeit (föleg a büntetőügyeken kívüli területen, noha itt sem végez igazgatási tevékenységet és rendeletalkotási joga sincs), de a bírói hatalom jegyeit is (kiváltképp a bírósági szakaszt, bírósági eljárást megelőző eljáráshoz kapcsolódó jogosultságok viszonylatában). Az ügyészség helyzetére vonatkozó alapvető rendelkezéseket az Alkotmány nyolcadik fejezetének első szakasza, a 149-151. cikkely tartalmazza:

1 A 2011-töl hatályos alkotmányszöveg magyar nyelven itt érhető el: http://hu.scribd.com/doc/71271450/ASzlovak-Koztarsasag-Alkotmanya (a szerk.). 
"149. cikkely

A Szlovák Köztársaság Ügyészsége védi a természetes személyek, a jogi személyek és az állam jogait és a törvény által védett érdekeit.

\section{0. cikkely}

Az ügyészség élén a legfóbb ügyész áll, akit a Szlovák Köztársaság köztársasági elnöke nevez ki és hív vissza tisztségéböl a Szlovák Köztársaság Nemzeti Tanácsának javaslata alapján.

\section{1. cikkely}

Az ügyészek kinevezésének és visszahívásának, jogainak és kötelességeinek és az ügyészség szervezeti felépitésének részleteit törvény szabályozza."

Az Alkotmány az ügyészséget alapvetően jogvédő egyetemes szervként hozta létre, amely a közérdek képviseletében cselekszik. Feladata a természetes személyek, jogi személyek és az állam jogainak és jogos érdekeinek a védelmezése. Az ily módon kijelölt feladatkör nyilvánvalóvá teszi, hogy az ügyészség a jogvédő, a törvényességet védelmező szervek rendszeréhez tartozik. Az is nyilvánvaló, hogy hatásköre (az alkalmazott eszközök) szempontjából az ügyészséget az ellenörző szervek közé lehet sorolni, amelyek legföbb feladata, hogy ellenőrizzék a törvényesség betartását, megállapítsák a jogsértéseket, és fellépjenek a törvényesség érdekében.

A fentebb említetteket alátámasztja az Alkotmánybíróság álláspontja, amely szerint „az ügyészségnek, mint a jogok és törvényes érdekek védelmét érvényre juttató szervnek, helye van az állami szervek rendszerében, s megvan a maga pótolhatatlan funkciója. [...]. A jogállamnak az az érdeke, hogy szervei megfelelő módon és következetesen teljesítsék a rájuk osztott feladatokat. Ott, ahol az állami szervek tevékenységükkel jogtalanul beavatkoznának a jogi személyek és a természetes személyek jogaiba és a jog által védett érdekeibe, az államnak kötelessége, hogy ellenőrző mechanizmusok rendszerét hozza létre e jogok védelmére. E mechanizmusok egyike az ügyészség. Pótolhatatlan szerepet játszik az ellenőrzés rendszerében, s ez adja, biztosítja létjogosultságát." ${ }^{2}$

Az ügyészség alkotmányos helyzetével kapcsolatban felmerülö leggyakoribb kérdés, hogy független-e az ügyészség, avagy sem. Az ügyészség definiálásának szemszögéböl kiemelhető, hogy a szlovák Alkotmány (s ez más, általánosan kötelező érvényű és a Szlovák Köztársaságban hatályos jogszabályokra is érvényes) nem független szervként határozza meg az ügyészséget. Amely szervek függetlenségét ugyanis az Alkotmány elismeri, azok esetében a függetlenséget kifejezetten le is szögezi [Alkotmány 60. cikkely (1), 141. cikkely (1) és 151. cikkely (1) bekezdés]. Azoknál a szerveknél, amelyeknél az Alkotmány nem kívánja a függetlenséget elismerni, nem is rendelkezik róla. Egyúttal megjegyezhető, hogy az ügyészség az em-

2 DRgonec, Ján: Ústava Slovenskej republiky (A Szlovák Köztársaság Alkotmánya), Komentár, Šamorín, Heuréka, 2004, 771. 
lített szerepét a törvény által rá ruházott hatáskörök birtokában anélkül is betöltheti, hogy a ,független” jelzőt társítanánk hozzá.

A fentiek alapján egyfajta részleges konklúzióhoz juthatunk. Az ügyészséget az Alkotmány a közhatalom önálló szerveként hozza létre, amely a büntetőeljárásban betöltött pótolhatatlan szerepen kívül - ahol is felügyeleti szervként ténykedik a pert megelőző eljárásban és vádlóként a bírósági szakban -, a büntetőeljáráson túlmenően is különböző feladatokat teljesít: mindenekelőtt felügyeletet gyakorol afelett, hogy a közigazgatás szervei miként őrzik meg a törvényességet. Egyúttal - ha ezt a közérdek megkívánja - bizonyos feladatokat a polgári peres eljárásban is ellát. Az ügyészséget olyan egyetemes szervnek lehet tehát tekinteni, amely az objektív jogot védelmezi a köz érdekében. Ezáltal különbözik néhány európai ország (pl. a Cseh Köztársaság, a Német Szövetségi Köztársaság, Ausztria) állami képviseleteitől. ${ }^{3}$

\section{Az ügyészség helyzetének törvényi szabályozása}

Az ügyészség helyzetének jogi szabályozását a 2001/153. sz. törvény (a továbbiakban: ügyészségi törvény) 2. §-a tartalmazza a következő megfogalmazásban: „Az ügyészség állami szervek önálló, hierarchikusan elrendezett, egységes rendszere, melynek élén a legföbb ügyész áll, s amelyben az ügyészek alá-fölé rendeltségi viszonyban tevékenykednek."

\subsection{Az ügyészség önállósága}

Az ügyészség önállósága abban fejeződik ki, hogy az ügyészség önállóan, a közhatalom más szerveitől elkülönülten teljesíti feladatait. Ezen túlmenően a közhatalom egyetlen szerve sem jogosult arra, hogy a legfőbb ügyésznek vagy bármelyik más ügyésznek utasításokat adjon. A közhatalom más szervének olyan feladatok teljesítésére sincs jogosultsága, amelyek kizárólag az ügyészség és az ügyészek jogkörébe tartoznak (pl. hogy vádat emeljen vagy hogy a vádlott tekintetében döntést hozzon az előkészítő eljárás során).

Megállapítható továbbá, hogy az ügyészség önállósága a szervezet finanszírozási módjában is kifejezést nyer. Az állami szervek együtteseként tevékenykedő ügyészség az állami költségvetés eszközeivel gazdálkodik, az állami költségvetésről szóló törvény alapján, amelyet a Nemzeti Tanács fogad el. Az állami költségvetésről szóló törvényben külön fejezet vonatkozik a Legfőbb Ügyészségre, amely a költségvetés e fejezetének a gazdája, s a keretén belül pénzügyi szempontból biztosítja az alárendelt ügyészségek tevékenységét. Az ügyészséget tehát megilleti a költségvetési autonómia. Az önálló pénzügyi fejezet lehetővé teszi, hogy a problémák alaposabb ismeretében, jobban lehessen reagálni a rendszer szükségleteire. Az ügyészség pénzügyi fejezete érvényesíti az Európai Unióban előnyben részesített szubszidiari-

3 KoudELKA, Zdeněk: Změny postavení státního zastupitelství (Az állami képviselet helyzetének változásai), In: Státní zastupitelství, 2008, 58. 
tás elvét is, amely azt határozza meg, hogy a közhatalmat - az igazgatást is beleértve - lehetőség szerint azon a szinten kell gyakorolni, amelyet érint.

Az Alkotmány 149. cikkelyéből [és az ügyészségről szóló törvény 3. § (1) bekezdéséből] az következik, hogy az ügyészség feladata a Szlovák Köztársaságban a természetes személyek, jogi személyek, valamint az állam jogainak és törvényes érdekeinek a védelme. Ebben az összefüggésben lényeges kiemelni, hogy az ügyészség a hatáskörében eljárva köteles a köz érdekében a törvényesség védelmére, köteles fellépni a törvényességet megsértőkkel szemben, köteles a jogsértések következményeinek elhárítását célzó intézkedéseket végrehajtani, és a jogsértésért viselendő felelősséget megállapítani. Hatáskörének gyakorlása során az ügyészség köteles az összes törvényes eszközt oly módon felhasználni, hogy a természetes személyek, a jogi személyek és az állam jogainak és törvényes érdekeinek a védelme minden befolyástól mentesen biztosítva legyen [ügyészségi törvény 3. § (2) bekezdés].

$E$ jogi normák teljesítésének nélkülözhetetlen előfeltétele az ügyész alapvető kötelességeinek teljesítése, amelyeket a 2001/154. számú, az ügyészekre és az ügyészségi fogalmazókra vonatkozó törvény 26 . § (1) bekezdése határoz meg. Megemlíthetők továbbá azon kötelességek, amelyek az Alkotmányból, az alkotmánytörvényekből, a törvényekből és a többi, általánosan kötelező érvényü jogi előírásból következnek az ügyész számára, és a sor folytatható a felettes ügyésztől kapott feladatokkal és utasításokkal, hogyha az ügyésszel megfelelően megismertték azokat. Ezek szerint védenie és szolgálnia kell a közérdeket; lelkiismeretesen, pártatlanul és felettesei utasításainak megfelelően kell teljesítenie szolgálati kötelességeit; nem hagyhatja egyéni vagy részérdekektől, politikai pártok vagy politikai mozgalmak érdekeitől befolyásolni magát, nem engedhet a közvélemény vagy a média nyomásának, s vissza kell utasítania minden olyan beavatkozást, nyomást, befolyást vagy kérést, amelyek veszélyeztethetnék pártatlanságát. Az objektivitás jegyében kell cselekednie, és figyelembe kell vennie minden lényeges körülményt, tekintet nélkül arra, hogy az valamely fél vagy az eljárás bármely résztvevője számára előnyös-e vagy hátrányos.

A fentebb ismertetett kötelességek némelyikének a fontossága Az igazságszolgáltatás rendszerének függetlenségét érintő európai normákról szóló jelentés II., Az ügyészség címủ részével is alátámasztható, amelyet a Velencei Bizottság fogadott el, 2010. december 17-18-án Velencében megtartott, 85. plenáris ülésén. Konkrétan kiemelhető a jelentés 15 . cikkelye, mely szerint „...az ügyésznek becsületesen és pártatlanul kell cselekednie. Azokban a rendszerekben is, ahol az ügyész nem része a bíráskodás intézményeinek, azt várják el, hogy oly módon fog cselekedni, ahogy a bíróságok.” A jelentés 17. cikkelye szerint „....a bíróhoz hasonlóan az ügyész sem járhat el olyan ügyben, amelyben személyesen érintett, s amelyben pártatlansága vagy függetlensége bármi módon csorbulhat, sérülhet."

Az ügyészség önállóságának tiszteletben tartása tehát szükséges, hiszen az ügyészségnek a továbbiakban is a közérdeket szolgálva s mindenfajta befolyástól mentesen kell ténykednie. Az ügyészség önállóságának tiszteletben tartása előfeltétele annak, hogy az ügyészek pártatlanul, harmadik személyek befolyásától mentesen gyakorolhassák jogosítványaikat. 


\subsection{Az ügyészségi szervezet hierarchikus elrendezése}

Az „ügyészség” fogalma alatt nem egyetlen önálló állami szerv értendő, hanem egymással hierarchikus viszonyban álló állami szervek együttese. Az ügyészséget az alábbi állami szervek alkotják:

- a Szlovák Köztársaság Legföbb Ügyészsége (a továbbiakban: Legföbb Ügyészség);

- kerületi ügyészségek (8);

- járási ügyészségek (54).

Az ügyészek alá- fölé rendeltségi viszonyban tevékenykednek. Az ügyészség hierarchikus elrendezése tükröződik az utasítási jog hierarchikus rendszerében is, ami azt jelenti, hogy az ügyész jogosult

- utasításokat adni az alárendelt ügyésznek, hogy miként cselekedjen az eljárás és a feladatok teljesítése során (azaz tartalmi és eljárási jellegü utasításokról egyaránt lehet szó);

- az eljárás egyes lépéseit az alárendelt illetékes ügyész helyett megtenni.

Az érvényes jogrend fontos garanciákat tartalmaz annak érdekében, hogy az ügyészeknek a feletteseiktől való, az ügyészség hierarchikus elrendezéséből fakadó függőségével ne lehessen visszaélni. Az ügyészségről szóló törvény konkrétan az alábbiakat szabályozza:

- az alárendelt ügyésznek kiadott utasítást írásban kell közölni;

- az ügyész a törvénnyel vagy saját jogi álláspontjával ellentétes utasítást megtagadhatja;

- az alárendelt ügyész megtagadhatja az utasítás teljesítését abban az esetben is, ha az utasítás végrehajtásával bűncselekményt, kihágást, más szabálysértést vagy fegyelmi vétséget követne el;

- az alárendelt ügyész megtagadhatja az utasítás teljesítését akkor is, ha a végrehajtással közvetlenül veszélyeztetné saját vagy hozzátartozója életét vagy egészségét.

Ezen túlmenően a 2011/220. számú, az ügyészségről szóló törvényt megváltoztató és kiegészítő, s néhány más törvényt is módosító törvény bevezette az ún. negatív utasítások tilalmát, mind a büntetőügyek tekintetében (ennek lehetőségét korábban csak a különleges ügyész és a Különleges Ügyészség Hivatala ügyészeinek viszonylatában szabályozták), mind a polgári ügyek terén. A törvény indoklása szerint ennek várható következménye az ügyészek perbeli függetlenségének megszilárdulása lesz. $E$ törvény alapján a felettes ügyésznek a továbbiakban nem áll jogában arra utasítani az alárendelt ügyészt, hogy ne indítson büntetőeljárást, ne emeljen vádat, ne javasolja a vádlott előzetes letartóztatását, az ügy tárgyalását egy másik szervnek adja át, szüntesse meg a büntetőeljárást, ne nyújtson be vádiratot s ne éljen rendes vagy rendkívüli jogorvoslati eszközzel a vádlott terhére. Hasonló felfogás érvényesül a polgári ügyekben is, amelyekben a felettes ügyész az új szabályozás szerint nem utasíthatja az alárendelt ügyészt arra, hogy az ne nyújtsa be a polgári peres eljárás megindítására vonatkozó javaslatot, ne kapcsolódjon be a már megkezdett polgári peres eljárásba, ne éljen jogorvoslattal a polgári peres eljárásban meghozott ítélet ellen, ne nyújtson be ügyészi tiltakozást vagy ne nyújtson be ügyé- 
szi figyelmeztetést. A 2011/220. sz. törvény megtiltja továbbá, hogy a felettes ügyész az említett eljárásbeli lépéseket maga tegye meg, és megtiltja neki azt is, hogy egy másik, alárendelt ügyészt utasítson ilyen lépés megtételére. Megjegyzem, a Legföbb Ügyészség nem ért egyet ezzel a változtatással, és a legföbb ügyész első helyettese normakontroll-indítványt nyújtott be az Alkotmánybíróságnak annak vizsgálatát kérve, vajon a 2011/220. sz. törvény némely rendelkezése összhangban van-e az Alkotmánnyal és az Emberi Jogok Európai Egyezményével (EJEE). ${ }^{4}$ Ezt követően az Alkotmánybíróság a PL ÚS 2011/105. sz. határozatban (Törvénytár, 2011/308. sz.) a megtámadott rendelkezések egy részét felfüggesztette. Az ügy érdemében azonban ez ideig nem döntött.

Jelen írás szerzőjének - saját tapasztalatai alapján - meggyőződése, hogy az ügyészség hierarchikus szervezetrendszere a törvények és más jogszabályok, valamint a büntetőpolitika egységes alkalmazásának nélkülözhetetlen előfeltétele. Az ügyészség hierarchikus szervezete az ügyészség rendes működésének előfeltételét jelenti, amivel a Büntetőügyek Európai Bizottsága (CDPC) is egyetért. Az utóbbi irányítása mellett megbízták az ügyészeknek a büntetőbíróságok rendszerén belüli helyzetét vizsgáló szakértői bizottságot (PC-PR), hogy vizsgálja meg, milyen az ügyészség helyzete és szerepe a büntetőbíróságok rendszerében az Európa Tanács egyes tagállamain belül. Ez következik az Európa Tanács tagállamainak Miniszteri Bizottsága által kiadott, $\operatorname{Rec}(2000) 19$-es ajánlás az ügyészségnek a büntetőbíróságok rendszerében betöltött szerepéröl címen ismert dokumentumból, amelyet az Európa Tanács Miniszteri Bizottsága 2000. október 6-án hagyott jóvá, továbbá az ajánláshoz készült indoklásból is.

\section{Az ügyészség szervezeti felépítése és hatásköre}

A legföbb ügyészt a Nemzeti Tanács javaslata alapján a köztársasági elnök nevezi ki. A legföbb ügyész hivatali ideje hét év. A különleges (vagy más néven speciális) ügyészt a parlament választja meg tisztségébe a legföbb ügyész javaslata alapján. A speciális ügyész hivatali ideje szintén hét év. A többi ügyészt a legföbb ügyész nevezi ki tisztségébe, időbeli korlátozás nélkül.

Az ügyészség legalsó szintjét a járási ügyészségek jelentik. $A$ járási ügyészség vezető ügyésze a járási ügyész, akinek egy vagy két helyettese van. A többi ügyészt a járási ügyészség ügyészeinek nevezik.

A kerületi ügyészségek vezetője a kerületi ügyész, akinek két helyettese van. A kerületi ügyészségek osztályokra tagolódnak, amelyek élén az osztályvezetők állnak. A többi ügyészt a kerületi ügyészség ügyészeinek nevezik.

A Szlovák Köztársaság Legföbb Ügyészségének és a Szlovák Köztársaság egész ügyészségének élén a legföbb ügyész áll. A Legföbb Ügyészség szekciókra, föosztályokra és osztályokra oszlik, amelyek élén a szekciók főigazgatói, a főosztályvezetők és az osztályvezetök állnak. A többi ügyészt a Legföbb Ügyészség ügyészeinek nevezik.

4 Bővebben lásd: www.genpro.gov.sk. 
A Különleges Ügyészség Hivatala a Legföbb Ügyészség részét képezi. A Különleges Ügyészség Hivatalának élén a különleges ügyész áll, $s$ a legföbb ügyész általa irányítja a Különleges Ügyészség Hivatalának tevékenységét. A speciális ügyész a legföbb ügyésznek felel hivatala ellátásáért. A Különleges Ügyészség Hivatalának jogkörébe tartozó ügyekben azonban a legföbb ügyész nem jogosult a speciális ügyésznek sem, ahogyan más ügyésznek sem, „negatív” utasítást adni, sem a speciális ügyész vagy a Különleges Ügyészség Hivatala ügyésze helyett eljárni, sem arról dönteni, hogy ilyen döntést vagy eljárást egy másik, alárendelt ügyész hajtson végre.

A Különleges Ügyészség Hivatalának ügyészeit a legföbb ügyész nevezi ki tisztségükbe pályázati eljárás alapján, a speciális ügyész javaslata nyomán, s az ügyészek tanácsának előzetes beleegyezését követően. A Különleges Ügyészség Hivatala által végzett feladatok teljesítésére kijelölt személyt a legföbb ügyész csak a különleges ügyész javaslatára hívhatja vissza a Speciális Ügyészség Hivatalában betöltött tisztségéből.

A különleges ügyészség és a Különleges Ügyészség Hivatalához tartozó ügyészek hatásköre a Büntető perrendtartás 14. §-a szerint a Különleges Bíróság hatáskörébe tartozó személyekre és cselekményekre vonatkozik (elsősorban korrupciós ügyek és a szervezett bűnözés). E hatáskör a Büntető perrendtartás 14. §-ának (1) bekezdése szerint azokra a hivatali büncselekményekre terjed ki, amelyeket KIK??? a hatáskört megalapozó hivatali időben (azaz a mandátum tartama alatt) követtek el, akkor is, ha a búncselekmény csak annak a hivatali időnek a leteltével került napvilágra, amely a hatáskört megalapozza. nem értem...

\section{A legföbb ügyész jogosultságai}

A legföbb ügyész a Szlovák Köztársaság ügyészségének az élén álló alkotmányos tényező. A legföbb ügyész hatáskörét az ügyészségről szóló törvény a jogkörei alapján tagolva, az alábbi szervekhez való viszonylatban szabályozza:

- az ügyészség szervei, az ügyészek és az ügyészség alkalmazottai;

- a Nemzeti Tanács;

- a Kormány;

- az Alkotmánybíróság;

- a Szlovák Köztársaság Legfelsőbb Bírósága;

- más szervek, külön törvényben meghatározott esetekben.

Az ügyészség tevékenységét a Szlovák Köztársaságban a legföbb ügyész irányítja és ellenőrzi. A feladatok teljesítése érdekében szolgálati utasításokat és útmutatásokat ad ki, amelyek minden ügyész, az ügyészségi fogalmazók (,az ügyészség jogász várományosai") és egyéb alkalmazottai számára kötelezőek. A törvények és más jogi normák egységes alkalmazása érdekében a legföbb ügyész állásfoglalásokat bocsát ki, amelyek minden ügyész számára kötelezőek. Emellett jogi és szervezési utasításokat bocsát ki, amelyek a Szlovák Köztársaság Törvénytárában jelennek meg. 
A 2011/220. sz. törvénnyel újraszabályozták az állásfoglalások kiadásának jogosultságát is. Ezzel a joggal konkrétan továbbra is a legföbb ügyész rendelkezik, aki azonban nem bocsáthat ki állásfoglalást saját kezdeményezésére, hanem csak az ún. Állásfoglalási Bizottság javaslatára. E bizottság hat tagból áll, akik közül hármat a legföbb ügyész nevez ki és hív vissza, hármat pedig az igazságügy-miniszter nevez ki és hív vissza.

A Legfőbb Ügyészség ezt a változtatást is bírálja, és a legföbb ügyész első helyettese javaslatot nyújtott be az Alkotmánybíróságnak annak vizsgálatára, hogy vajon a törvény összhangban van-e az Alkotmánnyal és az EJEE rendelkezéseivel. Mint már említettük, az indítvány nyomán az Alkotmánybíróság a megtámadott rendelkezések egy részét felfüggesztette, de az ügyben érdemben egyelöre nem döntött.

A legföbb ügyész más állami szervek tekintetében is jelentős jogosultságokkal rendelkezik. Évente egyszer beszámol az ügyészség tevékenységéröl a Nemzeti Tanácsnak, amelyben összegzi tapasztalatait a törvényesség aktuális helyzetéről. Javaslatot tehet a Nemzeti Tanács elnökének törvények elfogadására, megváltoztatására és kiegészítésére. A legföbb ügyész arra is jogosult, hogy javaslatot tegyen a Nemzeti Tanácsnak az alkotmánybírónak jelölt személyek megválasztását illetően.

A legföbb ügyésznek jogában áll, hogy a kormány útján a törvényhozásnak törvények elfogadását, megváltoztatását és kiegészítését javasolja.

A legföbb ügyész az Alkotmánybíróság felé:

- normakontroll-indítvánnyal élhet, kérve a jogszabályok összhangjának és alkotmányosságának vizsgálatát;

- az alkotmánytörvények értelmezését kérheti, konkrét alkotmányos jogvita esetén;

- panaszt tehet a parlamenti vagy a területi önkormányzati választások alkotmányellenessége vagy törvénytelensége, vagy a választások eredménye miatt;

- panaszt tehet a Szlovák Köztársaság elnökének megválasztásával vagy viszszahívásával kapcsolatos alkotmányellenesség vagy törvénytelenség miatt;

- panaszt tehet a Szlovák Köztársaság elnökének visszahívásáról szóló referendum, népszavazás eredménye miatt;

- javaslatot tehet valamely politikai párt vagy mozgalom feloszlatását vagy tevékenységének felfüggesztését elrendelő döntés felülvizsgálatára.

Mielött az Alkotmánybíróság döntene a jogi normák összhangjának tárgyában, a legföbb ügyész köteles az Alkotmánybíróság elé terjeszteni a tárgyalt üggyel kapcsolatos állásfoglalását, amennyiben az Alkotmánybíróság elnöke állásfoglalás megfogalmazására kéri. Mielőtt az Alkotmánybíróság döntene egy olyan határozat felülvizsgálatának a kérdésében, amely valamelyik politikai párt vagy mozgalom feloszlatásáról vagy tevékenységének felfüggesztéséről rendelkezik, a legföbb ügyész az Alkotmánybíróság elnökének vagy e bíróság szenátusa elnökének a kérésére köteles az Alkotmánybíróságnak benyújtani a tárgyalt üggyel kapcsolatos állásfoglalását.

A legföbb ügyésznek jogában áll, hogy a Legfelsőbb Bíróságnak javaslatokat tegyen a törvény egységes értelmezésének biztosítására vonatkozó (jogegységi) határozat kialakítására. Külön törvények alapján, s az e törvényekben meghatározott feltételek mellett jogában áll, hogy a Legfelsőbb Bíróság elé terjesszen:

- felülvizsgálati kérelmet; 
- rendkívüli felülvizsgálati kérelmet polgári peres eljárásban kiadott, jogerős döntés ellen;

- indítványt valamely politikai párt vagy mozgalom feloszlatására, politikai párt vagy mozgalom tevékenységének a felfüggesztésére.

A legföbb ügyész részt vehet a Legfelsőbb Bíróság plénumának ülésén. A legföbb ügyész a fentieken túlmenően kinevezi és visszahívja annak a bizottságnak az egyik tagját és e tag helyettesét, amelyik a veszélyeztetett tanú, a védett tanú és a hozzájuk közel álló személyek védelméről dönt, valamint további jogokat és kötelezettségeket gyakorolhat külön törvények és törvényben kihirdetett nemzetközi szerződések alapján.

\section{Az ügyészség hatásköre}

A hatályos szabályozás alapján a Szlovák Köztársaság ügyészsége jogvédő szervként az alábbi területeken gyakorolja hatáskörét:

a) Büncselekmények elkövetésével gyanúsított személyek elleni bünvádi eljárásban, illetve a törvényesség megörzését felügyelve a bünvádi eljárás megkezdése elött (az elökészítő eljárásban), külön törvényben meghatározott módon

Az ügyész egyes, a bűnvádi eljáráshoz kapcsolódó jogosultságait a Büntető perrendtartás rögzíti. Jelentősek továbbá az ügyész azon jogosultságai, amelyek a sértett jogainak biztosításához kapcsolódnak a Büntető perrendtartás vagy a 2003/514. számú, a közhatalom gyakorlása közben okozott kárért viselt felelősségröl szóló, a 2006/215. számú, az erőszakos bủncselekmények által megkárosított személyek kártalanításáról szóló, valamint az 1998/256. számú, a tanú védelméről szóló törvény alapján.

b) A törvényesség megörzését felügyeli azokon a helyeken, ahol a szabadságuktól megfosztott személyeket tartanak fogva, vagy olyan személyeket, akiknek a személyi szabadságát bírósági döntés vagy más, erre jogosult állami szerv döntése alapján korlátozzák

Az ügyész felügyel arra, hogy bírósági döntés alapján fogva tartásra, szabadságvesztés végrehajtására, katonák fegyelmi büntetéseire, kényszergyógykezelésre, fiatalkorúak nevelőintézetében való nevelésre, intézeti gyógykezelésre vagy intézeti nevelésre, továbbá a rendőrségi őrizetet (ill. az előzetes letartóztatást) szolgáló cellákban szabadságkorlátozó fogva tartásra csak arra illetékes szerv határozata alapján kerüljön sor. Felügyel ezeken a helyeken a jogszabályok betartására is. A felsorolt esetekben és a szóban forgó helyeken az ügyésznek jogában áll ellenőrzést végezni, szabadon bocsátani a törvénytelenül fogva tartott személyt, és megszüntetni vagy felfüggeszteni a törvénytelen döntés, parancs vagy intézkedés végrehajtását. Az ügyész a szabadságkorlátozást foganatosító intézményekbe bármikor beléphet, a hivatalos iratokba betekinthet, ellenőrizheti az ilyen intézmények által kiadott határozatok és intézkedések törvényességét, valamint négyszemközt beszélhet a fogvatartottakkal. 
c) A bírósági eljárásban

Az egyes jogosultságokat elsősorban a Büntető perrendtartás és az 1963/99. számú, a Polgári perrendtartásról szóló törvény $(\mathrm{Pp})$ tartalmazza. A büntetőeljárás terén a vádló tisztségét tölti be a bíróságon - tehát a közvádat képviseli vagy javaslatot tesz vádalkura.

A polgári peres eljárásban az ügyésznek a közérdek védelmezőjeként (az objektív jog védelmének szerveként) meghatározott esetekben jogában áll, hogy a Pp 35 . § (1) bekezdése és a Büntető törvénykönyv 86. §-a alapján polgári peres ejárást kezdeményezzen, a 35 . $§(2)$ bekezdése alapján pedig jogában áll bekapcsolódni a már megkezdett polgári peres eljárásba.

d) Az állam képviselete a bírósági eljárásban, ha erröl külön törvény rendelkezik

Ilyen lehet például az 1993/278. számú, az állami tulajdon kezeléséről szóló törvény, illetve az 1991/92. számú, az állami tulajdon más személyre való átruházásáról szóló törvény.

e) Az ügyészségről szóló törvény által meghatározott mértékben annak felügyelete, hogy a közigazgatás szervei betartják-e a törvényességet

Itt az ügyészség ún. nem büntetőügyi hatáskörének keretében megvalósuló felügyeletről van szó. Ennek során az ügyész felügyeletet gyakorol a közigazgatás szerveinek törvényes müködése felett: ellenőrzést tart e szerveknél, természetes vagy jogi személyek kezdeményezése alapján megvizsgálja a döntéseiket és az általuk kiadott normatív előírásokat. A felügyelet a büntetőügyeken kívüli területeken az alábbi eszközökkel gyakorolható: ügyészi tiltakozás, ügyészi figyelmeztetés és javaslattétel bírósági eljárás megkezdésére a Pp alapján.

A büntetöügyeken kívüli területen gyakorolt felügyelet (a büntetőügyek terén megvalósuló felügyelettől eltérően) nem foglal magában fölérendeltségi elemet. Az ügyész tehát nem adhat e szervekre kötelező utasításokat, s a törvény megsértéséért sem szabhat ki szankciót. Az Alkotmány 15. és 151. cikkelye értelmében tehát nem tölti be a felettes szerv szerepét. ${ }^{5}$

f) Olyan megelőző intézkedések előkészitésében és végrehajtásában való részvétel, amelyek a törvények és más jogszabályok megsértésének megelőzésére irányulnak; továbbá részvétel a büncselekmények okainak és feltételeinek felszámolásában és a bünözés visszaszorításában

Az ügyészek bűnmegelőző tevékenysége olyan területekre irányul, amelyek potenciálisan bủncselekmények elkövetésének a terét jelenthetnék, vagy közvetlenül összefüggnek a bűncselekmények elkövetésével. Az ügyészek a törvényből fakadó hatásköreiktől függően járási és kerületi szinten, valamint a Legfőbb Ügyészség szintjén kapcsolódnak be a megelőző tevékenységekbe.

g) A jogalkotásban való részvétel

Az ügyészségnek nincs joga arra, hogy a törvényhozás terén kezdeményező szerepet játsszon. Nem terjeszthet közvetlenül törvényjavaslatokat a Nemzeti Tanács elé megtárgyalás és jóváhagyás céljából. Ebből kifolyólag a törvények megalkotása során az ügyészség együttmüködik a Szlovák Köztársaság Igazságügyi Minisztériumával.

5 Hoffmann, Marian: Prokuratúra SR - orgán ochrany práva, Bratislava, Eurokodex, 2010, 39. 


\section{Befejezés}

Mindezek alapján a Szlovák Köztársaság ügyészségét széles hatáskörü bűnvádi és közérdekvédelmi intézménynek tekinthetjük. Változó közjogi státusza kapcsán a szerző - saját ügyészi tapasztalatai alapján is - azt támogatja, hogy ez a szervezet továbbra is tartalmilag önálló alkotmányos intézményként létezzen, és müködésébe más hatalmi ágak mind kevésbé avatkozhassanak be. 